\title{
DESENTRALISASI PELAYANAN PUBLIK DI KABUPATEN WONOSOBO
}

\section{Shadu Satwika Wijaya1*, Zaula Rizqi Atika1, Chamid Sutikno1, Muhammad Husnul Maab1, dan Diar Budi Utama²}

\begin{abstract}
${ }^{1}$ Dosen Program Studi Administrasi Publik, Universitas Nahdlatul Ulama, Purwokerto, Indonesia 2Mahasiswa Program Studi Manajemen Bencana, Universitas Pertahanan, Bogor, Indonesia *Email: ss.wijaya@unupurwokerto.ac.id
\end{abstract}

\begin{abstract}
Abstrak
Salah satu bentuk desentralisasi dalam pelayanan publik dapat dilihat dari pelaksanaan Pelayanan Administrasi Terpadu Kecamatan (PATEN). Maksud penyelenggaraan PATEN telah tercantum dalam Permendagri Nomor 4 Tahun 2010 Pasal 3 yang diantaranya mengamanatkan bahwa kecamatan sebagai pusat pelayanan masyarakat dan menjadi simpul pelayanan bagi kantor/badan pelayanan terpadu di kabupaten/kota. Penyelenggaraan PATEN sekaligus menambah peran kecamatan, bukan hanya mengkoordinasikan pelaksanaan pemerintahan desa, melainkan juga unit pelayanan publik. Kecamatan sebagai penyelenggara PATEN dianggap belum maksimal menyelenggarakan pelayanan publik sebagaimana yang diharapkan pemerintah kabupaten karena berbagai keterbatasan sehingga kurang mampu memberikan pelayanan yang optimal, serta keterbatasan sarana dan prasarana sehingga tidak mampu menyediakan kenyamanan dalam proses pelayanan publik. Kondisi demikian membuat masyarakat mengharapkan pemerintah agar keberadaan kecamatan mampu memenuhi seluruh kebutuhan pelayanan dasar masyarakat. Berdasarkan hal tersebut maka kajian Blue Print Pengembangan Kecamatan dalam Desentralisasi Pelayanan Publik di Kabupaten Wonosobo penting untuk dilaksanakan.

Kata Kunci: Desentralisasi, Pelayanan Publik, Wonosobo, Restrukturisasi, Penguatan Kecamatan
\end{abstract}

\section{PENDAHULUAN}

Pemerintah Indonesia sudah sejak lama mencanangkan desentralisasi pemerintahan. Bentuk desentralisasi dalam pelayanan publik salah satunya dapat dilihat dari pelaksanaan Pelayanan Administrasi Terpadu Kecamatan (PATEN). Maksud penyelenggaraan PATEN telah tercantum dalam Permendagri No 4 Tahun 2010 Pasal 3 yang diantaranya mengamanatkan bahwa Kecamatan sebagai pusat pelayanan masyarakat dan menjadi simpul pelayanan bagi kantor/badan pelayanan terpadu di kabupaten/kota. Penyelenggaraan PATEN ini sekaligus menambah peran kecamatan, bukan hanya mengoordinasi pelaksanaan pemerintahan desa, melainkan juga unit pelayanan publik. Data kunjungan pelayanan publik di salah satu Perangkat Daerah yang ada di Kabupaten Wonosobo, merupakan contoh gambaran bahwa pelayanan publik di tingkatan Perangkat Daerah saat ini sudah kurang ideal. Kator Disdukcapil harus melayani masyarakat sejumlah 835 orang setiap harinya. Dengan waktu dan sumber daya yang terbatas, maka pelayanan prima akan sulit dicapai. Akibatnya akan mengurangi kualitas pelayanan publik. Dengan persoalan tersebut, desentralisasi pelayanan publik benarbenar diperlukan.

Kabupaten Wonosobo, melalui Perbup Nomor 32 Tahun 2014 mengenai Pelimpahan Sebagian Urusan Pemerintahan Dari Bupati Kepada Camat Dalam Pelayanan Administrasi 
Terpadu Kecamatan (PATEN) dan Perbup Nomor 26 Tahun 2017 Tentang Perubahan Kedua Atas Peraturan Bupati Nomor 32 Tahun 2014, bermaksud mendekatkan pelayanan publik sampai pada tingkatan kecamatan. Tujuannya adalah agar masyarakat di Kabupaten Wonosobo lebih mudah dalam mengakses pelayanan publik, terutama yang lokasinya jauh dari pusat pemerintahan. Hasil penilaian SKM terhadap dua kecamatan di Kabupaten Wonosobo Tahun 2018, yakni Kecamatan Watumalang dan Kecamatan Kalikajar, menunjukkan bahwa masyarakat sudah puas dengan penyelenggaraan pelayanan publik di kecamatan.

Berdasarkan seluruh unsur pelayanan yang ada, hanya ada satu unsur yang nilainya masih dianggap kurang memuaskan oleh masyarakat adalah unsur waktu pelayanan. Nilai terbaik didapatkan oleh unsur biaya dan penanganan dalam pengaduan. Dalam pelaksanaannya ternyata kebijakan PATEN ini masih mengalami beberapa kendala. Kecamatan sebagai penyelenggara PATEN merasa belum dapat secara maksimal menyelenggarakan pelayanan publik sebagaimana yang diharapkan pemerintah kabupaten karena bebagai keterbatasan, seperti keterbatasan kewenangan yang menyebabkan petugas kecamatan harus tetap bolak balik ke kabupaten; keterbatasan kewenangan juga menyebabkan masyarakat harus mengurus beberapa urusan lainnya langsung ke kabupaten; keterbatasan SDM yang tidak sebanding dengan jumlah pemohon, sehingga kurang mampu memberikan pelayanan yang optimal, serta keterbatasan sarana dan prasarana sehingga tidak mampu menyediakan kenyamanan dalam proses pelayanan publik.

Perubahan Undang-Undang Otonomi Daerah dari UU Nomor 32 Tahun 2004 mengenai Pemerintahan Daerah dan UU Nomor 6 Tahun 2004 tentang Desa, menjadi UU Nomor 23 Tahun 2014 tentang Pemerintahan Daerah dan UU Nomor 6 Tahun 2014 tentang Desa, berdampak pada kondisi SDM kecamatan termasuk di Kabupaten Wonosobo. Sebagian besar pegawai kecamatan adalah eks sekretaris desa yang berstatus PNS. Karakteristik SDM yang pada awalnya seperti raja di desa, dilayani oleh beberapa staf, dipaksa menjadi pegawai pelayanan publik di kecamatan yang harus melaksanakan perintah atasan untuk melayani masyarakat. Kondisi tersebut pada akhirnya berpengaruh terhadap kinerja pelayanan publik kecamatan.

Di sisi yang lain, masyarakat sangat mengapresiasi atas kerja keras pemerintah dalam upayanya mendekatkan pelayanan publik sampai pada tingkatan kecamatan. Pengurusan KTP, KK dan Akte Kelahiran yang sekarang dapat diselesaikan di kecamatan, sangat memudahkan masyarakat dan mendorong motivasi masyarakat untuk lebih tertib administrasi. Dengan alasan tersebut, masyarakat menaruh harapan yang besar kepada pemerintah agar kecamatan lebih dimampukan lagi untuk menjadi simpul pelayanan publik, sehingga kecamatan benarbenar mampu memenuhi seluruh kebutuhan pelayanan dasar masyarakat. Dalam rangka mewujudkan pelayanan publik yang baik tersebut maka diperlukan suatu kajian tentang 
penyelenggaraan pelayanan publik di kecamatan, sehingga kecamatan mampu menyelenggarakan PATEN dengan baik. Berdasarkan hal tersebut, munculnya permasalahan yakni berkaitan dengan bagaimana pola pelayanan publik yang diselenggarakan oleh kecamatan saat ini, sekaligus mengidentifikasi permasalahannya dan gambaran tentang desain pelayanan publik di kantor kecamatan yang ideal dengan berbagai pelayanan urusan yang memungkinkan untuk diserahkan pengelolaannya kepada kecamatan untuk meningkatkan fungsi dan peran kecamatan dalam menyelenggarakan pelayanan serta dapat memenuhi perkembangan keadaan dan kebutuhan masyarakat saat ini. Adapun tujuan dari penyelenggaraan penelitian ini adalah untuk mendeskripsikan existing pola penyelenggaraan pelayanan publik di kantor kecamatan dan menyusun blue print pengembangan kecamatan dalam desentralisasi pelayanan publik.

\section{TINJAUAN PUSTAKA}

\section{Konsep Pelayanan Publik}

Sebagaimana yang telah diamanatkan oleh Menteri Pendayagunaan Aparatur Negara dalam Keputusan Nomor 63 tahun 2003 tentang Pedoman Umum Penyelenggaraan Pelayanan Publik menyatakan bahwa pelayanan publik merupakan pemenuhan keinginan dan kebutuhan masyarakat oleh penyelenggara negara. Menentukan mutu penyelenggaraan pelayanan publik sendiri, menurut Hakim (2014), ditentukan oleh minimal tiga faktor utama, yaitu aspek kelembagaan, aspek sumber daya manusia dan aspek sistem pelayanan.

\section{Aspek Kelembagaan}

Penyelenggaraan pelayanan publik akan berjalan dengan baik ketika diselenggarakan oleh lembaga dengan kondisi yang baik. Aspek kelembagaan ini tercakup beberapa hal, seperti struktur organisasi, job description, sistem pelayanan publik, dll. Keberadaan struktur organisasi ditetapkan sebagaimana tugas yang akan dibagi, siapa melapor kepada siapa, mekanisme koordinasi yang formal serta pola interaksi yang akan diikuti (Robbins, 1995). Dengan demikian, struktur organisasi mempunyai tiga komponen yang meliputi kompleksitas, formalisasi, dan sentralisasi.

Pelaksanaan Pelayanan Administrasi Terpadu Kecamatan (PATEN) sebagai bentuk pelimpahan kewenangan kepada camat serta tentunya memperkuat peran dan fungsi Kecamatan. Peran dan fungsi tersebut selain sebagai Satuan Kerja Perangkat Daerah dan pelaksanana tugas pemerintahan umum, tetapi juga sebagai unit pelayanan terpadu di Kecamatan. Selanjutnya, Kecamatan sebagai penyelenggara PATEN harus memenuhi persyaratan meliputi Substantif, pendelegasian sebagai wewenang Bupati/Walikota kepada Camat dalam bidang perizinan; Administratif, standar pelayanan dan uraian tugas personil kecamatan; dan Teknis, saranan prasaran dan pelaksana teknis. Terpenuhinya syarat 
tersebut membuat Kecamatan yang memiliki visi, misi, maklumat pelayanan, Standart Operating Procedure (SOP) meningkat akuntabilitas dan budaya kerja kecamatan.

2. Aspek Sumber Daya Manusia (SDM)

Aparatur pemerintah dapat didefinisikan sebagai kumpulan manusia yang mengabdi pada kepentingan negara dan pemerintahan, serta berkedudukan sebagai pegawai negeri (Tayibnapsis, 1993 dalam Achmad, 2010: 193). Adapun Moerdiono (1988) menyampaikan bahwa aparatur pemerintah merupakan segenap jajaran pelaksana pemerintah yang memperoleh kewenangannya melalui pendelegasian dari Presiden Republik Indonesia. Dengan kata lain aparatur negara atau aparatur adalah para pelaksana kegiatan dan proses penyelenggaraan pemerintahan negara, baik yang bekerja di dalam badan eksekutif, legislatif dan yudikatif maupun sebagai TNI, PNS Pusat dan Daerah, yang ditetapkan dengan peraturan peraturan pemerintah. Berkaitan dengan kualitas pelayanan publik, maka kemampuan aparatur pemerintah sangat berperan dalam menentukan kualitas pelayanan publik tersebut. Menurut beberapa para ahli mengemukakan peningkatan kualitas sumber daya aparatur (Sedarmayanti 2011:236 dalam Junidis, 2015) meliputi:

a. Keterampilan (skill), menjelaskan mengenai kompetensi tentang informasi atau ilmu yang dimiliki individu dalam bidang pekerjaan tertentu (Spencer, 1993:15).

b. Pendidikan. Hal ini nantinya akan mempengaruhi terhadap kompetensi seseorang (Anuas, 2009:18);

c. Pemberian kewenangan, dimana pekerja sebagai tukaran atas kontribusinya kepada organisasi (Werther dan Davis, 1996:379);

d. Pengembangan karier. Hal ini bertujuan agar seseorang bertanggung jawab sepenuhnya terhadap diri sendiri atas pelajaran yang diambil dan cara yang dicapai untuk mencapai tujuannya (Sedarmayanti, 2011:194).

e. Penempatan kerja sesuai bidang keahliannya. Mengaplikasikan aspek-aspek tersebut diharapakan para aparatur negara dapat meningkatkan kualitas pelayanan terhadap masyarakat (publik).

\section{Aspek Sarana dan Prasarana Pelayanan Publik}

Sarana adalah segala sesuatu yang dapat dipakai sebagai alat dalam mencapai maksud atau tujuan. Sedangkan prasarana adalah segala sesuatu yang merupakan penunjang suatu proses. Sarana prasarana pelayanan publik dapat diklasifikasikan menjadi dua, yakni Sarana prasarana utama, adalah sarana prasarana yang harus dalam penyelenggaraan pelayanan publik; dan Sarana prasarana pendukung, adalah sarana prasarana yang mendukung mutu pelayanan publik. 


\section{Teori Pilihan Publik (Public Choice)}

Buchanan (1984) menyampaikan bahwa teori pilihan publik menggunakan alat-alat dan metode-metode yang sudah dikembangkan hingga tingkat analisa canggih ke dalam teori-teori ekonomi dan diaplikasikan ke sektor politik atau pemerintah, ke ilmu politik atau ke ekonomi publik. Mengimplementasikan teori pilihan publik sering kali dipergunakan oleh para aktor politik maupun sebagai petunjuk bagi pengambilan keputusan dalam penentuan pilihan kebijakan publik yang paling efektif, karena kehadiran "teori pilihan publik" dapat menjadikan kerangka landasan dan batasan dari kerakusan sebuah kekuasaan yang mementingkan diri sendiri "greed of a selfish power", yang diharapkan pemangku kewenangan lebih mengutamakan pelayanan terhadap kepentingan publik (Downs, 1967). Teori pilihan publik membantu pemerintah dalam memberikan kerangka atau penjelasan mengenai bagaimana pemerintah mengambil keputusan.

\section{Reformasi Dan Desentralisasi Pelayanan Publik}

Manajemen pembangunan saat ini tengah mengalami proses transformasi paradigma dari pemerintahan (Government) ke tata pemerintahan (Governance) (Tjokroamidjojo, 2000). Governance is a conceptions on govering interactions. Interaction is a mutually influensing relation between two or more actors or entities (Kooiman, 2003). Collaborative governance adalah langkah tatanan pemerintahan dengan melibatkan semua pihak antara government, civil society, dan private sector dalam penyelenggaraan pemerintahan dengan kerangka egalitariansime serta demokrasi melahirkan tata pemerintahan yang mengedepakan kepentingan society.

Pergeseran paradigma government ke governance dimaksudkan untuk mendemokratisasikan administrasi negara. Government biasanya digunakan untuk merujuk pada struktur dan institusi pemerintah maupun organisasi formal, dalam kaitannya dengan pembuatan kebijakan sehingga pemerintah memainkan peran penting dalam mengendalikan masyarakat. Sedangkan governance mempunyai makna lebih luas, yaitu tradisi, institusi, dan proses yang menentukan pelaksanaan kekuasaan dalam masyarakat (Setyoko, 2011). Lokus dari administrasi negara ditentukan atas dasar keterlibatan dari organisasi atau lembaga tersebut pada upaya pengatasan dan penyelenggaraan public affairs dan public interest. Lokus dari administrasi negara bukan lagi lembaga pemerintah, melainkan masalah dan kepentingan yang dihadapi oleh publik sehingga banyak kelompok dan kepentingan yang terlibat secara langsung dalam perumusan dan pelaksanaan kebijakan publik (Nelissen, dalam Setyoko, 2011). Orientasi perubahan dari government ke governance meliputi beberapa aspek sebagai berikut:

1. sensitif dan responsif terhadap peluang dan tantangan baru yg timbul didalam pasar; 
2. tidak terpaku pada kegiatan-kegiatan rutin yang terkait dengan fungsi instrumental birokrasi. Harus mampu lakukan breakthrough yaitu keadaan dimana birokrasi mampu melalukan terobosan pemikiran dengan penuh kreatifitas dan inovasi;

3. memiliki wawasan yg futuristik dan sistematik;

4. berkemampuan untuk antisipasi, perhitungkan dan minimalkan resiko;

5. jeli terhadap potensi sumber-sumber peluang;

6. kemampuan mengombinasikan sumber menjadi resource mix yang mempunyai punya produktivitas tinggi;

7. kemampuan mengoptimalkan sumber yang tersedia dengan menggeser sumber dari aktivitas yang berproduktivitas rendah ke yang berproduktivitas tinggi (Propenko \& Pavlin, dalam Setyoko, 2011).

Pelakasanaan governace mengakibatkan adanya desentralisasi pelimpahan kewenangan dari pemerintah pusat ke daerah. Pergeseran paradigma dari government ke governance pada akhirnya menuntut penyelenggara negara untuk lebih terbuka terhadap setiap perubahan sosial di masyarakat. Aparatur pemerintahan harus mampu membuka diri untuk berubah demi mencapai perubahan yang berarti bagi jalannya tata pemerintahan yang baik. Perubahan ini dilakukan demi mencapai performa penyelenggara negara yang makin bersih bebas dari perilaku yang korup.

\section{METODE PENELITIAN}

Berdasarkan tujuan penelitian, maka metode penelitian yang digunakan meliputi: (1) Desk Study, yang dilakukan dengan tahapan mengumpulkan literature dan peraturan perundangan yang relevan dan melakukan diskusi dan pembahasan hasil pengumpulan literature dan peraturan perundangan dengan para pakar. Di samping itu, Metode kuantitatif digunakan untuk mejelaskan kondisi eksisting Kantor Kecamatan. Metode kualitatif digunakan untuk memperdalam serta menganalisis data dan informasi yang bersifat kualitatif yang diberikan oleh informan terutama berkaitan dengan kekuatan, kelemahan, peluang dan ancaman yang dihadapi oleh kecamatan di Kabupaten Wonosobo dalam upaya meningkatkan peran dan fungsinya sebagai simpul pelayanan publik. Sesuai dengan data yang dibutuhkan, maka teknik pengumpulan data yang digunakan antara lain: (1) Observasi, (2) Wawancara mendalam (in-depth interview), (3) Dokumentasi, dan (4) Focus Group Discussion (FGD),

\section{HASIL DAN PEMBAHASAN}

KONDISI EKSISTING PENYELENGGARAAN PELAYANAN KECAMATAN DI KAB. WONOSOBO

Penyelenggaraan pelayanan publik di kecamatan dapat dijelaskan dari tiga aspek, yaitu aspek kelembagaan, aspek sumber daya manusia, dan aspek sistem pelayanan. 


\section{Aspek Kelembagaan Pelayanan Publik di Kecamatan}

Secara kelembagaan, pelayanan publik PATEN di kecamatan sudah siap diselenggarakan. Hal ini dapat dilihat dari struktur organisasi dan kewenangannya.

a. Struktur Organisasi Kecamatan

Berdasarkan Perbup No 56 tahun 2016, PATEN dipimpin oleh kepala sub bagian di bawah kewenangan sekretaris kecamatan.

Gambar 1. Struktur Organisasi Kecamatan Kabupaten Wonosobo

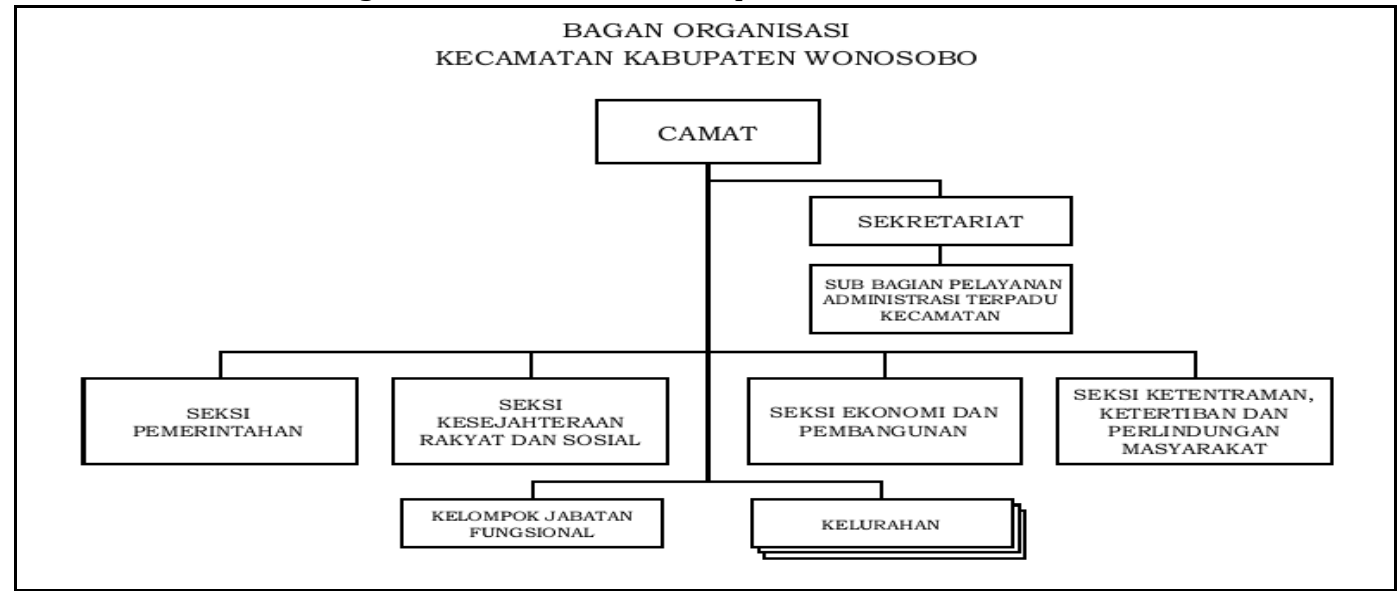

Berdasarkan struktur tersebut, maka dapat dibedakan tugas diantara ketiga jabatan di atas dalam penyelenggaraan pelayanan PATEN.

b. Kewenangan Kecamatan

Kabupaten Wonosobo telah menetapkan beberapa jenis pelayanan yang dilimpahkan kepada camat melalui perbup No 32 tahun 2014 mengenai pelimpahan sebagian urusan pemerintahan dari bupati kepada camat dalam pelayanan Administrasi Terpadu Kecamatan dan Perbup No 26 Tahun 2017 tentang perubahan kedua atas peraturan bupati no 32 tahun 2014. Jenis pelayanan yang dimaksud adalah:

Tabel 1. Ragam Pelayanan

\begin{tabular}{|c|c|c|}
\hline Perijinan & Non Perijinan & Legalisir \\
\hline $\begin{array}{ll} & \text { Ijin Mendirikan Bangunan } \\
& \text { (IMB) } \\
\text { - } & \text { Ijin Usaha Mikro Kecil (IUMK) } \\
\text { - } & \text { Ijin Pemasangan Reklame }\end{array}$ & $\begin{array}{ll}\text { - } & \text { Kartu Tanda } \\
\text { - } & \text { Penduduk } \\
\text { - } & \text { Kartu Keluarga } \\
\text { - } & \text { Kartu Identitas Anak } \\
\text { - } & \text { Akte Kelahiran } \\
\text { - } & \text { Diste Kematian } \\
\text { - } & \text { Surat Pindah }\end{array}$ & $\begin{array}{ll}- & \text { SKCK } \\
- & \text { Ahli Waris } \\
\text { - } & \text { Letter C/ Pengantar Bank/ SPPT } \\
\text { - } & \text { Numpang Nikah } \\
\text { - } & \text { Surat Keterangan Tidak Mampu } \\
& \text { (SKTM) } \\
\text { - } & \text { Keterangan lainnya }\end{array}$ \\
\hline
\end{tabular}

Sumber: Kecamatan Garung, Kab. Wonosobo, Tahun 2018

\section{Aspek SDM Pelayanan Publik di Kecamatan}

Penyelenggaraan pelayanan kecamatan di kabupaten wonosobo, dari aspek SDM, dapat dilihat dari sisi kualitas dan kuantitas. Secara kuantitas, SDM Kecamatan masih kurang dari standar. Berdasarkan Permendagri No 10 Tahun 2004 pasal 11, jumlah SDM pelaksana teknis yang dibutuhkan untuk menyeleggarakan pelayanan PATEN di kecamatan minimal memenuhi 
beberapa jabatan pekerjaan, antara lain Petugas informasi; Petugas loket/penerima berkas; Petugas operator komputer; Petugas pemegang kas; dan Petugas lain sesuai kebutuhan. Beberapa kecamatan yang telah disurvei, jumlah petugas teknis yang mengurusi pelayanan PATEN ternyata belum ideal. Rata-rata tiap kecamatan baru memiliki 3 - 4 petugas teknis. Jumlah tersebut belum memenuhi standar, dan kurang seimbang dengan jumlah pengguna layanan yang cukup banyak. Secara kualitas, SDM yang berada di bagian pelayanan belum seluruhnya berkompeten di bidangnya.

Kepala sub bagian PATEN yang betugas menyelenggarakan pelayanan PATEN, rata-rata sudah bergelar S1 dari berbagai jurusan ilmu, tetapi paling banyak adalah jurusan ilmu sosial. Adapun dari sisi umur, termuda adalah umur 36 tahun, dan tertua berumur 53 tahun. Apabila dirata-rata, maka kepala sub bagian PATEN adalah berumur 45 tahun. Adapun terkait dengan keberadaan staf kecamatan, maka rata-rata baru berpendidikan SMA (73\%). Jumlah staf yang berpendidikan S1 hanya 6\% dan D3 hanya 3\%. Untuk memberikan pelayanan yang prima, mengingat kondisi masyarakat saat ini yang sudah lebih melek informasi, tentunya petugas pelayanan publik memiliki latar belakang pendidikan minimal S1. Seluruh staff yang ada di kecamatan berusia di atas 30 tahun, dan kebanyakan berusia antara 50 - 60 tahun (53\%). Perlu diketahui bahwa usia produktif adalah usia seseorang antara 18 - 55 tahun. Dengan dasar itu, maka staf kecamatan yang bertugas menyelenggarakan pelayanan publik pada dasarnya sudah kurang produktif lagi.

\section{Aspek Sarana \& Prasarana Pelayanan Publik di Kecamatan}

Syarat teknis kecamatan dalam rangka menyelenggarakan pelayanan PATEN, berdasarkan Permendagri No 4 Tahun 2010 yaitu sanggup memenuhi seluruh sarana prasarana pelayanan. Sarana prasarana ini meliputi Loket/meja pendaftaran; Tempat pemrosesan berkas; Tempat pembayaran; Tempat penyerahan dokumen; Tempat pengolahan data dan informasi; Tempat penanganan pengaduan; Tempat piket; Ruang tunggu; dan Perangkat pendukung lainnya. Kondisi di lapangan, kecamatan baru mampu menyediakaan sebagian dari seluruh sarana prasarana pelayanan yang menjadi syarat teknis penyelenggaraan PATEN. Dengan segala keterbatasan, kantor kecamatan menyelenggarakan pelayanan dengan kondisi sebagai berikut:

a. Antara meja pendaftaran, pembayaran, penyerahan dokumen, dan penanganan pengaduan menjadi satu dalam meja pelayanan yang panjang, dan dipisahkan dengan tulisan saja;

b. Ruang tunggu sudah cukup memadahi;

c. Pengolahan data dan informasi berada di ruangan khusus, yang di dalamnya terdapat sarana pencetakan KTP dan KK;

d. Tempat pemrosesan berkas disediakan tersendiri berdekatan dengan tempat pengolahan data dan informasi. Beberapa diantaranya bahkan ada yang ruangannya bersamaan; 
e. Perangkat pendukung yang tersedia adalah perangkat rekam gambar untuk mendukung pelayanan pencetakan E-KTP. Sebagian kecamatan sudah menyediakan ruangan tersendiri untuk rekam gambar, tetapi sebagian yang lain masih menjadi satu dengan ruang tunggu, hanya dibatasi dengan meja atau pembatas yang lain;

f. Prasarana pendukung yang sudah tersedia adalah: ruang menyusui/ Laktasi dan toilet;

g. Mobil PATEN, yang disediakan oleh Pemerintah Kabupaten Wonosobo untuk setiap kecamatan satu unit, ternyata kondisinya kurang layak sehingga justru menyulitkan pihak kecamatan untuk mengelolanya.

Baik buruknya pelayanan tidak hanya dinilai dari kesesuaian pelaksanaan dengan perencanaannya saja, tetapi juga dinilai dari kepuasan masyarakat sebagai pengguna pelayanan. Berkenaan dengan sarana dan prasarana, masyarakat memberikan beberapa catatan yang perlu menjadi perhatian kecamatan selaku penyelenggara pelayanan, antara lain:

1) Tata ruang pelayanan yang masih kurang tepat, kurang strategis, sehingga terasa kurang nyaman digunakan

2) Tidak disediakannya prasarana pendukung dalam meningkatkan kenyamanan masyarakat saat menunggu pelayanan, seperti area bermain untuk anak-anak; buku bacaan; wifi; dan kantin,

3) Tidak semua masyarakat mengetahui tentang keberadaan mobil PATEN, dan tidak seluruh kecamatan memanfaatkan mobil PATEN tersebut untuk menunjang pelayanan PATEN. Hanya satu kecamatan yang berinovasi menyelenggarakan pelayanan Gone-des, yaitu pelayanan PATEN ke desa-desa menggunakan mobil PATEN, tujuannya adalah untuk mendekatkan pelayanan kepada masyarakat.

\section{Aspek Anggaran}

Aspek anggaran adalah aspek yang sangat penting, karena tanpa mendapatkan dukungan yang kuat dari aspek tersebut, maka setiap program pemerintah tidak akan dapat berjalan dengan optimal. Peraturan Pemerintah No 17 Tahun 2018 telah menjelaskan masalah pendanaan kecamatan. Dalam pasal 28 dijelaskan bahwa seluruh kegiatan yang berkenaan dengan tugas utama camat dibiayai oleh pemerintah. Hal ini tentunya mencakup pendanaan untuk forum koordinasi pimpinan di kecamatan dalam melaksanakan tugas untuk menunjang kelancaran pelaksanaan urusan pemerintahan umum di kecamatan.

Dapat diketahui bahwa kecamatan memiliki banyak anggaran yang sebenarnya bukan menjadi tupoksi Kecamatan, seperti program pembangunan fisik, yang sebenarnya sama sekali tidak mendukung Indikator Kinerja Utama (IKU). Sementara itu fungsi utama yang seharusnya diselenggarakan berupa forkompinca justru tidak mampu dianggarkan. Pelayanan publik yang saat ini sedang digencarkan pemerintah pun tidak mendapatkan porsi anggaran yang lebih besar. Padahal biaya pelayanan menjadi salah satu prasyarat penyelenggaraan pelayanan 
PATEN di kecamatan (Permendagri no 4 tahun 2010 pasal 8). Camat bertanggung jawab atas perencanaan pembiayaan pelayanan PATEN di kecamatan. Peraturan Pemerintah No 17 tahun 2018 Pasal 29 menjelaskan bahwa pelaksanaan tugas hasil pelimpahan wewenang kabupaten ke kecamatan seluruhnya dibebankan pada anggaran pendapatan dan belanja daerah kabupaten/ kota. Permendagri No 4 tahun 2010 pasal 21 menjelaskan bahwa penyelenggaraan PATEN dibiayai oleh Anggaran Pendapatan dan Belanja Daerah (APBD). Biaya penyelenggaraan PATEN sebagaimana yang dimaksud merupakan bagian yang tidak terpisahkan dari rencana kerja dan anggaran Kecamatan. Hal ini juga telah diatur dalam Peraturan Pemerintah No 17 Tahun 2018 tentang Kecamatan, bahwa Pendanaan pelaksanaan tugas PATEN dibebankan pada anggaran pendapatan dan belanja daerah kabupaten/ kota.

Berdasarkan hasil penelitian, dapat kita ketahui bahwa dari 15 kecamatan ada sepuluh kecamatan yang telah menganggarakan untuk Pos Anggaran Pelayanan Publik. Anggaran dengan nominal terbesar terdapat di Kecamatan Wonosobo, yaitu Rp 220.000.000,00 atau 0,89\% dari Total Anggaran. Sedangkan anggaran dengan persentase terbesar terdapat di kecamatan Kejajar, yaitu Rp 190.000.000,00 atau 2,94 \% dari total anggaran. Adapun anggaran terendah berada di kecamatan Kepil, yaitu Rp 10.000.000,00 atau 0,12 \% dari total anggaran. Sedangkan kecamatan yang belum mengaggarkan pos Anggaran Pelayanan Publik, yaitu Kecamatan Kaliwiro, Kecamatan Kertek, Kecamatan Sapuran, Kecamatan Selomerto, dan Kecamatan Sukoharjo.

Dari kesepuluh kecamatan yang telah menganggarkan Pos Anggaran Pelayanan Publik hanya ada dua kecamatan yang telah menganggarkan pos khusus untuk Pengembangan Pelayanan Administrasi Terpadu Kecamatan (PATEN), yaitu Kecamatan Wonosobo dan Kecamatan Leksono. Berdasarkan hasil penelitian, maka dapat kita ketahui bahwa secara umum untuk kedua kecamatan tersebut Pos Anggaran untuk Pengembangan Pelayanan Administrasi Terpadu Kecamatan (PATEN) terdiri dari Honorarium PNS; Belanja bahan habis pakai; Belanja jasa kantor; Belanja cetak dan pengadaan, dan Belanja makanan dan minuman. Dukungan dari pemerintah kabupaten terhadap penyeleggaraan PATEN dapat dilihat dari jumlah anggaran yang tercantum dalam APBD, dimana pelayanan umum ternyata sudah menjadi skala prioritas bagi pemerintah Kabupaten Wonosobo dalam menyusun anggaran belanja daerah.

\section{ARAH PENGEMBANGAN DESENTRALISASI PELAYANAN PUBLIK DI KECAMATAN}

Dalam rangka mewujudkan kecamatan yang ideal, khusunya dalam menyelenggarakan pelayanan publik, sehingga menjadi simpul pelayanan publik bagi masyarakat kecamatan, maka perlu disusun sebuah konsep kecamatan yang sehat, baik dari aspek kelembagaan, aspek sumber daya manusia dan aspek sarana dan prasarananya. 


\section{Aspek Kelembagaan}

Struktur organisasi dan kewenangan yang tepat akan berpengaruh terhadap kinerja organisasi. Begitu juga dengan kecamatan, untuk meningkatkan peran dan fungsinya sebagai simpul pelayanan publik di tingkat kecamatan, maka dari aspek struktur organisasi dan kewenangan harus disesuaikan, agar benar-benar mendukung tujuan kecamatan.

\section{a. Struktur Organisasi}

Struktur organisasi yang diterapkan pada kecamatan di Kabupaten Wonosobo ternyata berbeda dengan ketentuan dalam Permendagri No 4 Tahun 2010 tentang PATEN.

Tabel 2. Perbandingan Struktur Organisasi

\begin{tabular}{|l|l|l|}
\hline Aspek & Perbup No 56 tahun 2016 & Permendagri No 4 Tahun 2010 \\
\hline Penanggungjawab Penyelenggaraan & Sekretaris Kecamatan & Camat \\
\hline Penyelenggara & Sub Bagian & Seksi \\
\hline Pertanggungjawaban & Kepada Sekretaris kecamatan & Kepada Camat \\
\hline
\end{tabular}

Dalam permendagri telah diatur bahwa PATEN dikepalai oleh kepala seksi dan bertanggungjawab langsung kepada camat. Sedangkan di kabupaten Wonosobo, PATEN dikepalai oleh kepala sub bagian yang berada di bawah tanggung jawab sekretaris kecamatan. Dengan melimpahkan tugas penyeleggaraan PATEN kepada sekretaris kecamatan, secara tidak langsung telah mengurangi jatah kerja sekretaris kecamatan dalam mengelola mengelola kepegawaian, administrasi umum dan keuangan kecamatan secara keseluruhan yang benarbenar menjadi tanggungjawab utamanya. Untuk itu perlu diadakan restrukturisasi petugas kecamatan dengan berpedoman kepada Permendagri No 4 Tahun 2010, yaitu menempatkan urusan PATEN dalam struktur organisasi sebagai fungsi lini, bukan fungsi staf. PATEN perlu dirubah yang semula berada dibawah sekretariat kecamatan menjadi fungsi lini tersendiri sebagai seksi atau gabungan dari urusan lain pada satu seksi

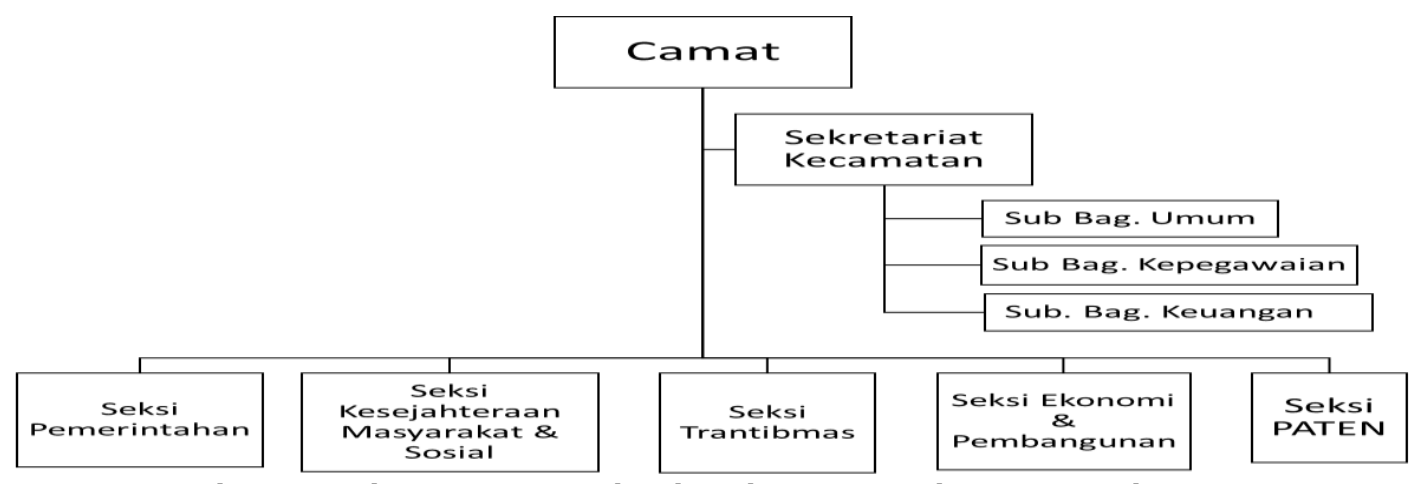

Gambar 1. Struktur Kecamatan berdasarkan Permendagri No. 4 Tahun 2010 Sumber: Permendagri No. 4 Tahun 2010

Berdasarkan Permendagri No 4 Tahun 2010, struktur kecamatan yang awalnya terdiri dari 4 (empat) seksi, bertambah menjadi 5 (lima) seksi, yakni dengan tambahan seksi PATEN. Dengan perubahan ini, dapat dipastikan bahwa PATEN diselenggarakan oleh kepala seksi dan bertanggungjawab langsung kepada camat. Sedangkan sekretaris kecamatan, benar-benar mengelola kebutuhan kecamatan secara umum. 


\section{b. Kewenangan dan Jenis Pelayanan}

Pad aspek kewenangan, bukan berarti bahwa tingkat kecamatan tidak bisa mempunyai peranan yang lebih penting daripada desa dalam konteks desentralisasi pelayanan publik di masa depan. Terdapat dua pilihan untuk memaksimalkan potensi kecamatan, yaitu:

1) Fungsi kecamatan bisa diperkuat dan disesuaikan menjadi perpanjangan tangan fungsi otonomi pemerintah kabupaten. Segala bentuk pelayanan publik yang sifatnya administratif merupakan jenis pelayanan yang cocok untuk didelegasikan kewenangannya pada tingkat kecamatan;

2) Kecamatan bisa berfungsi sebagai asosiasi pemerintah-pemerintah desa yang otonom. Selain itu juga dapat menjadi fasilitator daripada kerjasama antar pemerintah desa \& inovasi desa.

Berdasarkan pemahaman tersebut, maka pendelegasian wewenang pemerintah kabupaten kepada kecamatan adalah mutlak dibutuhkan untuk meningkatkan peran dan fungsi kecamatan sebagai simpul pelayanan publik. Berdasarkan Peraturan Pemerintah No 17 Tahun 2018 tentang Kecamatan pasal 11, Kecamatan mendapatkan pelimpahan kewenangan dari pemerintah kabupaten berupa menyelenggarakan pelayanan terpadu berupa pelayanan perizinan dan non perizinan.

Penyelenggaraan pelayanan perizinan memiliki kriteria diantaranya proses sederhana; objek perizinan berskala kecil; tidak memerlukan kajian teknis yang kompleks; dan tidak memerlukan teknologi tinggi. Penyelenggaraan_pelayanan non perizinan, memiliki kriteria meliputi berkaitan dengan pengawasan terhadap objek perizinan; kegiatan berskala kecil; dan pelayanan langsung pada masyarakat yang bersifat rutin.

\section{Aspek Sumber Daya Manusia}

Dalam rangka menciptakan pelayanan publik yang baik, perlu disediakan SDM yang memadai, yakni SDM yang produktif. Adapun produktivitas SDM paling tidak didukung oleh dua hal, yakni aspek usia dan aspek keterampilan dan pendidikannya. Berdasarkan hasil riset yang dilakukan oleh Happiens, dijelaskan bahwa usia seseorang menentukan bentuk kebahagiaannya dalam pekerjaan. Dalam kaitannya penyelenggaraan pelayanan publik, maka SDM yang cocok dan tepat untuk menjadi pegawai pelayanan publik adalah SDM yang usianya berada di kisaran umur 18 s.d. 54 tahun karena masih memiliki motivasi yang tinggi dalam bekerja. Hal ini dapat diketahui dari motivasinya dalam bekerja, dimana bagi SDM yang berumur 18 - 34 tahun, kebahagiaan kerja adalah ketika mereka memperoleh pengakuan atau penghargaan dari orang lain, baik dalam bentuk ucapan ataupun imbalan jasa. Selanjutnya SDM yang berusia 35 - 54 tahun, kebahagiaan mereka dalam bekerja diperoleh dari kemampuannya dalam memberikan sumbangsih kepada organisasinya. Dalam usia ini loyalitas pegawai terhadap organisasi sangat tinggi. Mereka sudah tidak lagi hanya memperhatikan 
gaji, melainkan juga pengabdian. Berbeda dengan SDM yang berusia 55 tahun ke atas, kebahagiaan kerjanya didapat ketika mereka memperoleh kedudukan dan posisi yang terhormat, atau dihormati dan disegani orang lain. Salah satu cirinya adalah merasa lebih atau paling ahli, sehingga suka memberikan nasehat, ceramah, atau strategi kerja kepada orang lain bahkan suka memerintah orang lain, tetapi lambat dalam pekerjaan teknis dan tidak suka diatur oleh orang lain. SDM di usia ini pada dasarnya sudah tidak cocok lagi untuk mejadi bawahan, apalagi staf pelayanan publik. Dalam aspek pelayanan publik di kecamatan tersebut, maka perlu ditetapkan petugas dengan kualifikasi pendidikan yang tepat disertai dengan pelatihan yang mendukung tugas dan tanggungjawabnya, meliputi beberapa jabatan dibawah meliputi Petugas informasi; Petugas loket/ penerima berkas; Petugas operator komputer; Petugas pemegang kas; dan Petugas lain sesuai kebutuhan.

\section{Aspek Sarana \& Prasarana Pelayanan Publik}

Sarana prasarana dalam penyelenggaraan pelayanan publik sangat besar peranannya dalam mewujudkan pelayanan publik yang berkualitas. Dengan alasan tersebut maka perlu ada upaya pengelolaan sarana dan prasarana pelayanan publik yang baik, yaitu pengelolaan sarana prasarana yang menerapkan beberapa prinsip di bawah ini:

a) Prinsip pencapaian tujuan;

b) Prinsip efisiens;

c) Prinsip Administratif;

d) Prinsip kejelasan tanggung jawab;

e) Prinsip kekohesifan.

Berdasarkan pada prinsip di atas, maka di bawah ini dikemukakan beberapa sarana prasarana dasar yang dibutuhkan untuk menyelenggarakan pelayanan publik di kecamatan,

Tabel 3. Standar Sarana \& Prasarana Pelayanan PATEN di Kecamatan

\begin{tabular}{|c|c|c|c|}
\hline NO & & Sarana & Prasarana \\
\hline \multirow[t]{5}{*}{1} & \multirow{5}{*}{$\begin{array}{l}\text { Sarana Prasarana } \\
\text { Utama } \\
\text { Penyelenggaraan } \\
\text { Pelayanan Publik }\end{array}$} & Customer Service & $\begin{array}{l}\text { Meja CS, petunjuk/prosedur } \\
\text { pelayanan }\end{array}$ \\
\hline & & Ruang Tunggu & $\begin{array}{l}\text { Tempat duduk dan suasana yang } \\
\text { nyaman }\end{array}$ \\
\hline & & \begin{tabular}{ll}
\multicolumn{2}{l}{ Ruang Pelayanan } \\
- & Pendaftaran \\
- & Pengaduan \\
- & Pembayaran \\
- & Penyerahan Berkas \\
\end{tabular} & Pembatas yang jelas \\
\hline & & Ruang Pengolahan Berkas & $\begin{array}{l}\text { Ragam prasarana yang } \\
\text { dibutuhkan untuk mengolah } \\
\text { berkas }\end{array}$ \\
\hline & & \begin{tabular}{ll}
\multicolumn{2}{l}{ Ruang Tindakan } \\
$-\quad$ Rekam Gambar \\
$-\quad$ Cek kesehatan \\
\end{tabular} & $\begin{array}{l}\text { Ragam prasarana yang } \\
\text { dibutuhkan untuk melakukan } \\
\text { tindakan }\end{array}$ \\
\hline \multirow[t]{5}{*}{2} & \multirow{5}{*}{$\begin{array}{l}\text { Sarana Prasarana } \\
\text { Pendukung } \\
\text { Penyelenggaraan } \\
\text { pelayanan publik }\end{array}$} & Kids playground & \\
\hline & & Ruang baca & \\
\hline & & Internet & \\
\hline & & Kantin & \\
\hline & & Tempat Ibadah & \\
\hline
\end{tabular}




\begin{tabular}{|c|c|c|}
\hline NO & Sarana & Prasarana \\
\hline & Tempat Ibu Menyusui & \\
\hline & Perbankan & Mesin ATM \\
\hline & Kantor Pos & \\
\hline & PATEN Mobile & Mobil Pelayanan \\
\hline & Lahan Parkir & \\
\hline & P3K & \\
\hline
\end{tabular}

\section{Aspek Anggaran}

Anggaran merupakan satu instrumen penting di dalam manajemen karena merupakan bagian dari fungsi manajemen. Dalam PP No 58 tahun 2005 tentang Pengelolaan Keuangan Daerah pasal 16 telah dijelaskan bahwa APBD mempunyai fungsi otorisasi, perencanaan, pengawasan, alokasi, distribusi, dan stabilisasi.

Melihat fungsi anggaran tersebut maka anggaran kecamatan sedapat mungkin sejalan dengan tupoksi. Kecamatan harus berupaya me-realokasi-kan anggaran kecamatan kepada pos-pos anggaran yang sesuai tupoksi dan mendorong peningkatan mutu pelayanan publik. Salah satu contohnya adalah peganggaran penyelenggaraan PATEN. Hal ini akan mampu menopang IKU kecamatan dan sebagai wujud keseriusan kecamatan dalam menyelenggarakan pelayanan publik. Selanjutnya, anggaran adalah bagian dari aktivitas penting yang dilakukan secara rutin. Dalam rangka penyusunan anggaran kecamatan, khususnya dalam penganggaran penyelenggaraan PATEN, terdapat beberapa prinsip penganggaran yang perlu dicermati, yaitu:

1. Transparansi dan Akuntabilitas Anggaran

Rencana Kerja dan Anggaran (RKA) Kecamatan harus dapat menyajikan informasi yang jelas mengenai tujuan, sasaran, hasil, dan manfaat yang diperoleh masyarakat dari pelayanan PATEN yang diselenggarakan.

2. Disiplin Anggaran Belanja

Belanja yang dianggarkan pada setiap pos/pasal merupakan batas tertinggi pengeluaran belanja. Oleh karena itu pemerintah kabupaten harus mencantumkan anggaran PATEN secara khusus di dalam APBD/ APBD Perubahan agar dapat diakses oleh selurh kecamatan.

3. Keadilan Anggaran

Berdasarkan hasil penelitian, dapat diketahui bahwa anggaran peningkatan pelayanan publik untuk kecamatan baru 0,68 \% dari total anggaran kabupaten dalam pelayanan administrasi pemerintahan. Aspek keadilan di tingkat kecamatan juga perlu diperhatikan, yakni adanya keseimbangan anggaran di setiap seksi, dimana PATEN yang kedepannya disejajarkan degan seksi yang lain, maka anggaran PATEN pun perlu disetarakan dengan seksi yang lainnya.

4. Efisiensi dan Efektivitas Anggaran

Penyusunan RKA sebaiknya didasarkan pada rasionalisasi kebutuhan penyeleggaraan seluruh kegiatan kecamatan, termasuk penyeleggaraan PATEN, sehingga anggaran yang 
ditetapkan dalam RKA adalah anggaran yang benar-benar tepat sasaran, efektif dan efisien, minimal dapat memenuhi seluruh persyaratan penyelenggaraan PATEN

\begin{tabular}{|c|c|}
\hline No & Pembiayaan \\
\hline 1 & $\begin{array}{l}\text { Honorarium Tenaga PATEN } \\
\text { - } \quad \text { Petugas informasi; } \\
\text { - } \quad \text { Petugas loket/ penerima berkas; } \\
\text { - } \quad \text { Petugas operator komputer; } \\
\text { - } \quad \text { Petugas pemegang kas; dan } \\
\text { - } \quad \text { Petugas lain sesuai kebutuhan. }\end{array}$ \\
\hline 2 & $\begin{array}{l}\text { Belanja Bahan Pakai Habis } \\
-\quad \text { Belanja Alat Tulis Kantor } \\
-\quad \text { Belanja Dekorasi Dokumentasi dan Publikasi (Iklan, Spanduk, dan lain-lain) }\end{array}$ \\
\hline 3 & $\begin{array}{l}\text { Belanja Cetak dan Pengadaan } \\
\text { - } \quad \text { Belanja Cetak } \\
\text { - } \quad \text { Belanja Pengadaan } \\
\end{array}$ \\
\hline 4 & $\begin{array}{l}\text { Belanja penunjang } \\
\text { - } \quad \text { Biaya Pelatihan SDM pelayanan publik } \\
\text { - } \quad \text { Belanja makanan dan minuman rapat koordinasi } \\
\text { - } \quad \text { Belanja transportasi/ operasional petugas PATEN } \\
\text { - } \quad \text { Belanja minuman dalam pelayanan masyarakat } \\
\end{array}$ \\
\hline 5 & $\begin{array}{l}\text { Belanja sarana dan parasarana } \\
-\quad \text { Pengadaan dan atau pengembangan sarana prasarana pelayanan }\end{array}$ \\
\hline
\end{tabular}

5. Disusun Dengan Pendekatan Kinerja

RKA Kecamatan disusun dengan pendekatan kinerja, yaitu mengutamakan upaya pencapaian hasil kerja (output/outcome) dari perencanaan alokasi biaya yang telah ditetapkan.

\section{KESIMPULAN}

Pemerintah Kabupaten Wonosobo melalui Perbup No 56 Tahun 2016, secara resmi telah menjalankan program Pelayanan Administrasi Terpadu Kecamatan (PATEN) di seluruh kantor kecamatan, dengan bentuk pelayanan yang berbeda-beda di setiap kecamatan sesuai dengan kemampuan sumber daya kecamatan masing-masing. Pelaksanaan PATEN yang kurang optimal di setiap kecamatan secara umum disebabkan oleh empat hal, yaitu: struktur organisasi yang kurang sesuai dengan tujuan organisasi dan kewenangan kecamatan yang masih terbatas; SDM yang masih kurang memadahi baik dari sisi kualitas maupun kuantitas; begitu juga dengan sarana dan prasarananya; dan keterbatasan anggaran yang menyebabkan kecamatan kurang leluasa dalam mengembangkan atau meningkatkan mutu pelayanan publik. Harapan masyarakat yang tinggi terhadap optimalisasi fungsi kantor kecamatan menjadi simpul pelayanan publik masyarakat perlu didukung oleh kesediaan dari pemerintah kabupaten dalam mendelegasikan beberapa urusan pelayanan publik kepada kecamatan disertai dengan kelengkapannya. Kantor kecamatan perlu mendapatkan perhatian khusus dengan mendesain ulang struktur, SDM, sarpras, dan anggarannya sehingga mampu memberikan pelayanan secara optimal. 


\section{DAFTAR PUSTAKA}

Achmad, Mansyur. 2010, Teori-Teori Mutakhir Administrasi Publik, Rangkang Education, Yogyakarta.

Downs, Anthony. 1967, A Rand Corporation Research Study, Little, Brown And Company, Inside Bureaucracy, Boston.

Kooiman, Jan. 2003, Governing As Governance, Sage Publications Inc, United States.

Noor, Muhammad. 2012, Memahami Desentralisasi Indonesia, Anggota Ikapi Interpena, Yogyakarta.

Paul A, Samuelson Dan William D. Nordhaus. 1993, Mikro Ekonomi, Terjemahan Drs. Haris Munandar Dkk, Edisi Ke-14, Erlangga, Jakarta.

Tjokroamidjojo, Bintoro. 2000, Good Governance, Paradigma Baru Manajemen Pembangunan, Ui Press, Jakarta.

\section{Jurnal}

Ansell, C., dan Gash, A. 2008, "Collaborative Governance In Theory And Practice", Journal of Public Administration Research And Theory, 18, 543-571.

Hakim, Rezha Yahya Nur, Heru Ribawanto, Dan Minto Hadi. 2014, "Pelayanan Publik Di Kecamatan Giri Kabupaten Banyuwangi (Studi Pada Penyelenggaraan Pelayanan Kependudukan)", Jurnal Administrasi Publik (Jap), Volume 2, Nomor 3, Hal. 518-524.

Junidis. 2015, "Kualitas Pelayanan Publik Di Kecamatan Kayan Selatan Kabupaten Malinau", Ejournal Ilmu Pemerintahan, 3 (4), 2015: 1502-1512

Robbins, Stephen P. Teori Organisasi, Struktur, Desain Dan Aplikasi, Edisi 3, 1994, Penerbit Arcan, Donaldson, Lex American Anti-Management Theories Of Organization, A Critique of Paradigm Proliferation, 1995, Cambridge, University Press.

Setyoko, Paulus Israwan, Moh. Imron, dan Denok Kurniasih. 2017, "Problems Of Public Accountability In Village Government Business Management (Study on Village Business Enterprises in Banyumas, Indonesia)", Journal of Public Administration and Governance, Volume 7, Nomor 4, Indonesia.

Tasrin, Krismiyati dan Putri Wulandari. 2012, "Kajian Pengaruh Kebijakan Desentralisasi Pada Peningkatan Kesejahteraan Masyarakat (Studi Kasus: Kabupaten/Kota Di Provinsi Jawa Barat)", Jurnal Borneo Administrator, Volume 8, Nomor 2.

\section{Sumber Lain:}

Statistika Daerah Kabupaten Wonosobo Tahun 2017.

Kabupaten Wonosobo Dalam Angka Tahun 2018. 